\title{
The impact of business environment reforms on poverty, gender and inclusion
}

Keir Macdonald

Institute of Development Studies (IDS)

4 January 2021

\section{Question}

- How do business environment reforms affect inclusion with regard to poverty and gender?

- How do male and female-led firms and employees experience business environments differently?

\section{Contents}

1. Summary

2. Business environment reforms, poverty and inclusion

3. Business environment and gender

4. Indonesia case study

5. References

The K4D helpdesk service provides brief summaries of current research, evidence, and lessons learned. Helpdesk reports are not rigorous or systematic reviews; they are intended to provide an introduction to the most important evidence related to a research question. They draw on a rapid deskbased review of published literature and consultation with subject specialists. 


\section{Summary}

This rapid review synthesises the literature from academic, policy, and knowledge institution sources on how business environment reforms in middle-income countries impacts on poverty, gender and inclusion. Although, there is limited evidence on the direct impact of business environment reforms on poverty, gender, and inclusion, this review illustrates that there is evidence of indirect effects of such reforms.

Business environment reform (BER) targets inadequate business regulations and institutions, in order to remove constraints to business investment and expansion, enabling growth and job creation, as well as new opportunities for international business to contribute to and benefit from this growth. However, there is a lack of detailed knowledge of the impact of BER on gender and inclusion (G\&l) outcomes, in terms of the potential to remove institutional barriers which exclude formerly marginalised groups from business opportunities, in ways that promote equal access to resources, opportunities, benefits, and services.

The literature shows how the business environment affects women in business, and how women's experiences of a given business environment can be different from those of men. This is the result of disparities in how they are treated under the law, but also based on structural and sociocultural factors which influence how men and women behave in a given business environment and the barriers they face. For example, these factors affect women's access to capital, their ability and incentives to license their businesses, and the size of their firms and sectors in which they operate.

There is evidence that suggest that women-led enterprises are smaller and in less productive sectors. In the literature this is explained partly by factors such as the education and skills available to women. For example, a lack of experience and contacts in higher-skilled sectors could contribute to women becoming entrepreneurs owing to an inability to secure well-paying formal employment. Women may also find it more difficult to travel for business in some specific countries. Furthermore, women are typically time-poor compared with men, owing to dual domestic and business roles, and as such are less able to spend significant amounts of time in bureaucratic processes.

The question is how these disparities can be tackled by business environment reforms, such as better licensing laws, land registration rules, or labour laws. While this review of existing literature finds no evidence of a direct link between BER, poverty and inclusion, indirect links are likely through the influence of BER on firm behaviour and performance. There is evidence from Indonesia that in regions where licensing reforms was implemented effectively, there was an increase in firm performance. Outside of the region of Jakarta, female-led firms saw better performance improvements than male-led firms. However, it should also be noted that unequal benefit for men and women from the same intervention as a result of sociocultural factors, give men more advantage of opportunities. Tailoring business environment reforms to tackle gender and inclusion issues by taking into account sociocultural dimensions, therefore, is necessary. Although there is an abundance of evidence around the disparities of women and other minority groups in the business environment and the call for reforms to take away specific barriers, a significant knowledge gap remains in how to understand direct and indirect impacts of such reforms on gender and inclusion. 


\section{Business environment reforms, poverty, and inclusion}

There is no evidence in the literature of a direct link between business environment reforms, poverty and inclusion. Given the number of other variables involved, it is hard to make clear causal links between reforms and changes in poverty and inclusion levels (White \& Fortune, 2015; Wennman et al, 2017). However, business environment reforms can lead to changes in business activity which in turn can lead to outcomes which increase job creation, incomes, and economic growth, all of which can lead to poverty reduction and greater inclusion (White \& Fortune 2015; Rahman 2014).

The success of many BERs is measured in terms of their contribution to economic growth, but there is little evidence of a direct link between reforms and economic growth. White \& Fortune (2015) identify an association between quality of business regulation and growth, but this is a general concept, and the research does not demonstrate links between specific reforms and growth. White \& Fortune (2015) and Rahman (2014) find links between reforms and better firm performance, with reforms removing some specific barriers for doing business. The assumption is that this will then lead to poverty reduction and inclusion through income generation and job creation.

White \& Fortune identify four key areas of business environment reform:

- Simplification of business registration and licensing procedures;

- Tax policies and administration reform;

- Improvement of labour laws and administration systems; and

- Land titles, registers and administration reform.

These four key areas have been studied individually to ascertain their effectiveness in improving firm performance and creating income and jobs. Business licensing reforms are linked with some improvements in performance. White \& Fortune's (2015) review of the literature shows that De Mel et al (2012) find that formalisation in Sri Lanka led to an increase in profits, with Boly (2015) finding similar results in Vietnam. However, there is little evidence showing that such reforms significantly increase formalisation. Bruhn (2011) in Mexico, Warner (2012) in Peru, and Rothenberg et al (2016) in Indonesia show that such reforms often do not have significant impacts on firms' incentives to formalise, and that there is a tendency for informal firms to remain informal.

There are clearly other factors beyond licensing procedures which must be addressed in order to incentivise informal firms to formalise. As such, Wennmann et al (2017) note that many firms in the informal economy will not be affected by business environment reforms. The lack of incentive to formalise has implications for firm performance, and poverty and inclusion. Rahman (2014) notes the differential in productivity between formal and informal firms in many low- and middleincome countries, and the correlation between informality and poverty. However, there is more required than just licensing reform in order to ensure that businesses formalise and that the benefits are realised by all businesses. Wennmann et al (2017) identify some issues arising from reforms incentivising formalisation, namely that they can create perverse outcomes, such as formalisation disproportionately benefitting large businesses at the expense of smallholders in Rwanda. 
Quak \& Flynn (2019), citing IFC (2013), note that business reforms can have a positive effect on firm registration and job creation, but that newly registered firms also tend to have less chance of survival than those registered prior to reforms, ensuring that firm performance and job creation are less certain. In addition, the link between firm performance and poverty reduction and increased inclusion relies on many other factors. Quak \& Flynn (2019) show that large firms are likely to create better paying, more stable jobs than small firms, although Spratt et al (2018) note that smaller firms can have a "multidimensional role" in reducing poverty, being better placed to serve communities, provide products to the poor, and be more adaptable to women's work lives. The question of reducing poverty and increasing inclusion is not as simple as helping businesses to formalise and improve their performance.

Regarding tax reforms, the IFC (2013) show the benefits of an effective tax regime not only in increasing a country's tax base and helping to facilitate investment, but also in reducing the compliance burden on small businesses which can help them to improve their performance, which is again seen to be a way to increase inclusion and reduce poverty through job creation and income generation. White \& Fortune (2015) also conclude that streamlining tax regimes can improve firm performance, particularly when firms move into the formal sector from the informal sector. Again, this demonstrates that reforms are intended to benefit firm performance which can indirectly contribute to greater inclusion and poverty reduction.

There is good evidence that reform of labour regulations does affect business decisionmaking, but that the impact on poor workers varies. On the one hand, BER may protect workers, helping to reduce the risks of exclusion from the labour force. On the other hand it can reduce opportunities, particularly for young and inexperienced workers, which is particularly pertinent for small and medium-sized enterprises (SMEs), given the higher costs associated with meeting labour regulations, as well as the important role that SMEs play in generating employment opportunities (White \& Fortune, 2015).

Quak \& Flynn (2019) show that there is a significant body of literature demonstrating that in lower-income countries there is a relationship between more stringent labour regulations and reliance on informal employment, although they cite Chari et al (2017) showing that in subSaharan Africa there is no strong evidence for over-regulation being responsible for labour market rigidities, and that frequently labour regulations are not enforced. Quak \& Flynn also note that subsidies for youth employment can have a positive effect, but only for the term of the subsidies, although the duration of impact can be increased if subsidies are combined with skills training. As such there are clearly many factors which must be considered alongside labour regulation reform in order to have a positive impact on poverty reduction and inclusion.

In a review of the literature, White \& Fortune find evidence that land titling and registration reforms lead to greater investment and growth of businesses. However, they also demonstrate that there is very little evidence positively linking land titling to improved access to credit. They also note that the link between land titling and poverty reduction is disputed: while it can lead to growth and investment, they note that there are studies showing that land titling is not a significant limiting factor in poverty reduction.

While the literature cannot demonstrate a direct link between business environment reforms and poverty reduction, there are many causal mechanisms linking reforms with businesses' abilities to grow, generate income, and create jobs, which in turn are linked with poverty reduction and inclusion. 


\section{Business environment and gender}

There is even less evidence of the impact of business environment reforms as discussed above on gender, particularly with respect to the impact of reforms in specific functional areas on women as business owners or employees. However, the literature does discuss how the business environment affects women in business, and how women's experiences of a given business environment can be different from those of men. This can be owing to differences in how men and women are treated by the law, but more often is the result of structural or sociocultural factors which affect how men and women behave in a given business environment and the barriers they face. Understanding how women experience the business environment can be linked with the above discussion of how reforms can affect inclusion more broadly to infer how women might be affected by certain reforms.

\section{Differences between male and female businesses in LMICs}

In order to understand why men and women experience the business environment differently, it is important to understand the differences observed between male and female business leaders and employees in lower- and middle-income countries (LMICs). In many LMICs, female-led firms are fewer and smaller than those of their male counterparts (Loscocco et al 1991; Ellis 2008; Simavi, Manuel \& Blackden 2010; Bardasi, Sabarwal \& Terrell 2011; Klapper \& Parker 2011). They may also operate in different sectors. Female employees have also been observed to be more prominent in certain sectors (Klapper \& Parker 2011). These factors are partly explained by the education and skills available to women. For example, a lack of experience and contacts in higher-skilled sectors can lead to women's exclusion from these sectors (Klapper \& Parker 2011; OECD 2017), and can also contribute to women becoming entrepreneurs owing to an inability to secure well-paying formal employment.

Female-led firms are found in retail and textile sectors in Europe \& Central Asia and in SubSaharan Africa (Bardasi, Sabarwal \& Terrell, 2011). In Vietnam, female-led firms were found to focus on traded goods as opposed to production (Van Steveren \& Akram-Lodhi, 2003). However, looking in more detail at countries within Sub-Saharan Africa, the particular sectors favoured by men and women change between country, with little overall pattern (Bardasi, Blackman \& Guzman, 2007). Differences in business size were more universal across all geographies globally tended to show the same pattern, however, with women-led firms tending to be smaller, and also fewer in number.

Both female-led firms and female employees are often observed to underperform their male counterparts across a broad range of metrics including income, growth, and, in the case of firm ownership, longevity of firm (Klapper \& Parker 2013). Again, though, the specific differences vary by region and by metric, with gender gaps being observed in productivity metrics in Europe \& Central Asia and Latin America but not Sub-Saharan Africa, and in growth metrics only in Latin America (Bardasi, Sabarwal \& Terrell, 2011).

\section{Explaining the differences: legal and sociocultural factors}

The reasons behind these differences can be legal or sociocultural. Some legal differences have a clearly negative impact on women's ability to run a business on equal terms with men. For example, legal restrictions on women's property ownership restrict access to business financing 
owing to lack of collateral, in particular in the Middle East and North Africa region (OECD, 2017; Simavi, Manuel \& Blackden, 2010). Interestingly, this contrasts with the more general conclusion drawn above by White \& Fortune (2015) that property rights do not represent a significant barrier to financing. Restrictions on women's travel in certain areas are cited as a disadvantage in terms of their ability to perform business activities. In regions where traditional law predominates, it can disempower women. For example, in Cameroon and Tanzania, women's property ownership and inheritance rights can be severely restricted, resulting again in a lack of access to capital or loan collateral (World Bank, 2008).

Differences in the legal treatment of men and women also affect employment, with greater differences leading to lower female employment. This relationship holds across both rich and poor nations, for male- and female-owned businesses, and for small and medium companies, although does not hold for larger companies (Amin, 2012). In Burkina Faso, for example, labour laws restrict women's working hours ostensibly to allow for more of a balance of work with domestic roles, but making female candidates less attractive as employees (Bedford, 2009). Antidiscrimination laws have attempted to redress such imbalances. An example is Rwanda which, despite having a broadly deregulatory approach to business and labour markets, still maintains quotas for female representation in the workforce (Bedford, 2009). While these studies do not relate the results to firm performance, they demonstrate that gender differences in laws have a clear impact on gender and inclusion.

A six-country study by the OECD (2017) shows that even where there are few gender disparities under the law, male- and female-led businesses operate in markedly different ways due to structural and sociocultural factors affecting the business environment, and women have very different employment prospects from men. Three relevant themes which emerge from the literature: business registration procedures, size and sector of business, and access to capital. In all of these cases women experience the business environment very differently from men despite there being no legal discrimination between the two.

Women may be disproportionately negatively affected by complex business registration processes, which affect both the number and size of female-led firms (Bardasi, Blackman \& Guzman, 2007), and whether or not they formalise. In Kenya, for example, far more women operate in the informal sector than in the formal sector, with women perceiving difficulties in the business registration process as a far greater issue than for men (Ellis, 2008). In Uganda, women are disproportionately affected by onerous licensing procedures, with $40 \%$ of female-led businesses claiming that these procedures were an obstacle to their growth compared with $30 \%$ of male-led businesses (Bardasi, Blackman \& Guzman, 2007; World Bank, 2008; Ellis, 2008). A pilot programme in Entebbe in which licensing procedures were simplified saw first-time business registrations of female-led firms which were $33 \%$ higher than males.

In LMICs, women are typically time-poor compared with men, owing to dual domestic and business roles, and as such are less able to spend significant amounts of time in bureaucratic processes. Lower levels of education and business contacts among women make this process harder (Simavi, Manuel \& Blackden, 2010; Ellis, 2008). Additionally, women are sometimes seen as easier targets for extracting bribes or 'facilitation' payments, including in the form of sexual favours, when going through business registration processes (World Bank 2008; Simavi, Manuel \& Blackden 2010). For example, a study of bureaucratic processes in the health and education 
sectors in Bangladesh found that women are more likely than men to be asked for "speed payments" in order to expedite processes (Oxford Policy Management 2007).

The gender differences between sectors and firm size can also affect how women experience the business environment. As outlined above, firms which are led by and predominantly employ women tend to be smaller and often located in different sectors to men, although specific patterns vary by country. Firm size in turn affects the likelihood of formalisation, since for smaller firms, the time required and costs of registering are relatively more impactful than for larger businesses (Ellis, 2008). As noted above, formalisation can lead to greater firm performance, but this benefit is less likely to fall to women if they are in firms whose size precludes them from formalising.

The tax regime has further negative impacts on small businesses and businesses in certain sectors. Small businesses lack economies of scale and pay more VAT on inputs than larger firms, as a percentage of income (Van Steveren \& Akram-Lodhi, 2003). Sector also affects how firms experience the business environment, including the tax regime. In Vietnam, female-led businesses are more likely to be in the traded goods sector, to which the standard 10\% VAT applies. The male dominated production sector has a VAT of $5 \%$ for "essential inputs", resulting in a greater chance that a male-run businesses will pay less VAT (Van Steveren \& Akram Lodhi, 2003).

Male and female-run firms operating in the same business environment can have very different experiences of being able to access capital. Size itself is a factor, which negatively affects the ability to raise finance (Loscocco et al., 1991). Commonly, women have less access to appropriate collateral, particularly in environments where they have weak ownership rights (World Bank 2008; Klapper \& Parker 2011; OECD 2017). "Immovable" assets which are often accepted as capital by lenders are typically owned by men, while women own assets such as jewellery which are less acceptable (OECD, 2017). In addition, women may be less able to travel to financial institutions, due to safety concerns, care responsibilities or men's control over their movements (Chamlou, 2008; OECD 2017). On the other hand, while access to capital is clearly correlated with business success, as women often work in less capital-intensive industries, the relative importance for firm performance may be less pronounced (Klapper \& Parker, 2011).

Given that the business environment affects women in business in significant ways which are different than for men, we can reasonably expect that the impact of BER will also vary significantly. This is reflected in the experiences of women regarding other, non-business environment interventions. Quak \& Flynn (2019) discuss how in agricultural commercialisation interventions, commercialisation pathways transforming food systems can create new low-paid farm jobs for women, but that women are likely to yield to men taking advantage of commercial farming activities. This demonstrates an unequal benefit for men and women from the same intervention as a result of sociocultural factors, with men more likely to take advantage of opportunities, often to do with social norms and access to resources which encourage or discourage engagement by women in certain activities. 


\section{Indonesia case study}

It is helpful to understand these dynamics through the examination of literature on a case study. There is sufficient literature on the business environment, gender, and inclusion in Indonesia to make this a useful study.

\section{Business and gender in Indonesia}

Women are highly active in running enterprises in Indonesia, although these tend to be smaller than those led by men, and concentrated in specific sectors of the economy. Roughly $60 \%$ of all micro, small and medium-sized enterprises (MSMEs) across the country are estimated to be run by women (Hani et al., 2012); while men control over $60 \%$ of medium and large enterprises in urban areas (Isiandari and Anandhika, n.d.; Babbitt et al., 2015; IFC and USAID, 2016). Womenled firms dominate in labour-intensive sectors which have relatively lower skill, technology, and capital requirements, including food, garment, and textiles. In textiles and garments, for example, almost $90 \%$ of micro and small enterprises are led by women (Istiandari and Anandhika, n.d.). Women also dominate in the trade, hotel and restaurant sectors (Arsana and Alibhai, 2016; Tambunan, 2009). Men dominate in manufacturing, technology, and capital-intensive industries (IFC and USAID, 2016).

A very high percentage of firms in Indonesia are informal, characterised by small size, low productivity, low wages, serving local markets, having managers with low educational attainment and lacking legal status and protections (Babbitt et al., 2015; Rothenberg et al., 2016). One attempt to estimate the size of this sector found more than $93 \%$ of all firms in Indonesia are informal (Rothenberg et al., 2016). Informal firms face a number of particular challenges beyond small size and low productivity. For example, reasons cited for informal enterprises in Indonesia to seek formalisation include greater security of operation, especially for those from ethnic minority groups, and to improve access to credit, especially for women-led businesses (Babbitt et al., 2015).

Many small, informal firms led by women are what may be termed 'necessity' rather than 'growthoriented' enterprises, without an intention or ability to grow but providing vital livelihoods for the individuals involved. According to the Global Entrepreneurship Monitor, 19 percent of all entrepreneurial activity in Indonesia is necessity driven, but 36.8 percent in the case of women (Kelley et al., 2015) and 71-76 percent amongst early-stage female entrepreneurial activities. Growth-oriented women entrepreneurs in Jakarta have cited lack of support from the family and difficulty in getting a business license, as well as "other" constraints like inflation and market access as key barriers (Tambunan, 2017). When registering businesses, women in Indonesia are also more likely to report illegal payments as an issue (IFC and USAID, 2016), although gender is not the only factor to affect registration processes, with education, affluence and age also important.

\section{Business registration reforms in Indonesia}

A series of reforms addressing complex and difficult licencing procedures were implemented in 2010-2012 (Asia Foundation, 2011; Rothenberg et al., 2016). These reforms reduced the number of procedures required and the cost involved in registering a business, and created an online service (World Bank 2013a) to expedite the process. It was estimated that if the reforms could 
cut the time necessary to expand a business by 4.5 days, it would raise the willingness of companies to invest by 10 percent, as well as reducing the opportunity for bribery and corruption (Ing et al., 2015; Steer 2006). One of these reforms was the PTSP reform introduced in 2009, setting out a framework delegating licensing authority to one single agency (Mourougane 2012), in a bid to streamline business licensing through one-stop shops and reduce licensing costs (Steer, 2006; Rothenberg et al, 2016).

Although implemented with differing levels of success in different regions, assessments of the reform in terms of simplifying licensing procedures and improving costs have broadly been positive (Wahid 2013, Anwar 2015, Umar et al 2019). However, one study which assessed whether the reform encouraged formalisation found little evidence that the programme reduced the rates of informality (Rothenberg et al., 2016). Recent research analysing World Bank Enterprise Survey data demonstrates that this reform had impacts which varied by geography, and by gender (Saha et al, 2021). Overall, in regions where the reform was implemented effectively, there was an increase in firm performance. Outside of the region of Jakarta, femaleled firms saw better performance improvements than male-led firms. It also demonstrated an increase in medium and large firms, with these increases marginally favouring women over men outside of Jakarta. However, the reform had no significant effects on employment (Saha et al., 2021).

As with the broader literature, this case study demonstrates the differences between how men and women experience the same businesses environment, the attempt to increase inclusion and reduce poverty through the introduction of business registration reforms, and interestingly how different regions experience the same reform, with rural regions having a different experience from more urbanised regions. The case study also highlights the gap in the Indonesian literature linking reforms to gender. This gap appears to exist across the literature and is an area in which further research should be done, in order to establish fully the nature of the effects of business environment reforms on gender.

\section{References}

Amin, M. (2012) 'Gender Disparity in Laws and Female Employment' Mimeograph

Anwar, M.K. (2015) 'Transformasi model inovatif untuk pelayanan terpadu satu pintu (PTSP) di Indonesia', Jurnal Otonomi Daerah dan Pengembangan Masyarakat

Arsana, G.P., Alibhai, S. (2016) Women Entrepreneurs in Indonesia: A Pathway to Increasing Shared Prosperity Jakarta: World Bank

Asia Foundation (2011) Local Economic Governance

Babbitt, L.G., Brown, D., Mazaheri, N. (2015) 'Gender, Entrepreneurship, and the FormalInformal Dilemma: Evidence from Indonesia', World Development 72: 163-174. https://doi.org/https://doi.org/10.1016/j.worlddev.2015.02.019

Bardasi, E., Blackden, M., \& Guzman, J.C. (2007) Gender, Entrepreneurship, and Competitiveness in Africa, Washington, D.C.: The World Bank 
Bardasi, E., Sabarwal, S. \& Terrell, K. (2011) 'How do female entrepreneurs perform? Evidence from three developing regions', Small Business Economics 37: 417-441

https://doi.org/10.1007/s11187-011-9374-z

Bedford, K. (2009). 'Doing Business with the Ladies: Gender, Legal Reform, and Entrepreneurship in the International Finance Corporation', Labour, Capital and Society / Travail, Capital Et Société, 42(1/2): 168-194

Boly, A (2015) On the benefits of formalization; panel evidence from Vietnam, UN WIDER Paper 2015/038

Bruhn, M. 2011 'License to Sell: The Effect of Business Registration Reform on Entrepreneurial Activity in Mexico', Review of Economics and Statistics 93(1): 382-386

Chamlou, N. (2008) The Environment for Women's Entrepreneurship in the Middle East and North Africa, Washington, D.C.: The World Bank

Chari, A.; Flynn, J.; Mader, P.; Mwaura, G.; Oosterom, M.; Roelen, K.; Samkpakra, R.; Ibrahim Shittu, A., \& Sumberg, J. (2017) Business Environment Reform Facility: Barriers to Job Creation and Labour Market Access for Youth in Sub-Saharan Africa, London: Department for International Development (DFID)

De Mel, S., McKenzie, D., Woodruff, C. (2012) 'One-Time Transfers of Cash or Capital Have Long-Lasting Effects on Microenterprises in Sri Lanka', Science 24, 962-966

Ellis, A. (2008) Gender and Economic Growth in Kenya: Unleashing the Power of Women, Washington D.C. : World Bank

Hani, U., Rachmania, I.N., Setyaningsih, S., Putri, R.C. (2012) 'Patterns of Indonesian Women Entrepreneurship Ummu Hania*, Ilma Nurul Rachmaniaa,Santi Setyaningsiha,Rucita Cahyawati Putria', Procedia Econ. Finance 4: 274-285

IFC (2013) IFC jobs study: Assessing private sector contributions to job creation and poverty reduction, Washington D.C.: World Bank

IFC \& USAID (2016) Women-owned SMEs in Indonesia: A Golden Opportunity for Local Financial Institutions Market Research Study, Washington D.C.: World Bank

Ing, L.Y. (2015) Business Licensing: A Key to Investment Climate Reform, Working Papers DP2015-05, Economic Research Institute for ASEAN and East Asia (ERIA).

Istiandari, R., Anandhika, M.R. (n.d.) The Role of Gender in Micro and Small Enterprise Business Development in Indonesia: A Firm-level Analysis, Asia Pacific Foundation.

Kelley, D., Singer, S., Herrington, M. (2015) Global Entrepreneurship Monitor, 2015/16 Global Report, London : Global Entrepreneurship Research Association.

Klapper, L.F., \& Parker, S.C. (2011) 'Gender and the Business Environment for New Firm Creation', The World Bank Research Observer 26(2): 237-257

https://doi.org/10.1093/wbro/lkp032 
Loscocco, K.A., Robinson, J., Hall, R.H., \& Allen, J.K. (1991) 'Gender and Small Business Success: An Inquiry into Women's Relative Disadvantage', Social Forces 70(1): 65-85 https://doi.org/10.1093/sf/70.1.65

Mourougane, A. (2012) Promoting SME development in Indonesia, OECD Economics Department Working Papers, No. 995, Paris : OECD Publishing https://doi.org/10.1787/5k918xk464f7-en

OECD (2017) Women's Economic Empowerment in Selected MENA Countries: The Impact of Legal Frameworks in Algeria, Egypt, Jordan, Libya, Morocco and Tunisia, Competitiveness and Private Sector Development, Paris: OECD Publishing http://dx.doi.org/10.1787/9789264279322-en

Oxford Policy Management (2007) Governance, Management and Performance in Health and Education Facilities in Bangladesh: Findings from the Social Sector Performance Qualitative Study, Oxford: Oxford Policy Management

Rothenberg, A.D., Gaduh, A., Burger, N.E., Chazali, C., Tjandraningsih, Radikun, R., Sutera, C., \& Weilant, S. (2016) 'Rethinking Indonesia's Informal Sector,' World Development 80. 96113

Quak, E-J. and Flynn, J. (2019) Private Sector Development Interventions and Better-Quality Job Creation for Youth in Africa, Leiden: Include Knowledge Platform

Rahman, A. (2014) Investment Climate Reforms and Job Creation in Developing Countries: What Do We Know and What Should We Do?, World Bank Policy Research Working Paper 7025, Washington D.C.: World Bank

Saha, A., Thorpe, J., Macdonald, K. \& Megersa, K. (2021). Linking business environment reform with gender and inclusion: A study of business licensing reform in Indonesia. K4D Emerging Issues Report No. 39. Brighton, UK: Institute of Development Studies. DOI: 10.19088/K4D.2021.001. https://opendocs.ids.ac.uk/opendocs/handle/20.500.12413/15902

Simavi, S., Manuel, C., \& Blackden, M. (2010) Gender dimensions of investment climate reform, Washington D.C.: World Bank

Spratt, S.; O'Flynn, P. and Flynn, J. (2018) DFIs and Development Impact: An Evaluation of Swedfund, EBA Report 2018:01, Stockholm: Expert Group for Aid Studies

Steer, L. (2006) Business Licensing and One Stop Shops in Indonesia, The Asia Foundation

Tambunan, T.T.H. (2009) 'Women Entrepreneurs in Indonesia: their main constraints and reasons', Journal of Asia Entrepreneurship and Sustainability 5: 37-51

Tambunan, T.T.H. (2017) 'Women Entrepreneurs in MSEs in Indonesia: Their Motivations and Main Constraints', International Journal of Gender and Women's Studies 5: 88-100

Umar, A. et al (2019) 'One-stop service policy as a bureaucratic reform in Indonesia', Academy of Strategic Management Journal 18(2) 
Van Steveren, I. \& Akram-Lodhi, A.H. (2003) A gender analysis of the impact of indirect taxes on small and medium enterprises in Vietnam, The Hague: Institute of Social Studies

Wahid, F. (2013) 'Translating the Idea of the eGovernment One-Stop-Shop in Indonesia', in Mustofa, K., Neuhold, E.J., Tjoa, A.M., Weippl, E., You, I. (eds) Information and Communication Technology, ICT-EurAsia 2013. Lecture Notes in Computer Science, vol 7804. Springer, Berlin, Heidelberg. https://doi.org/10.1007/978-3-642-36818-9_1

Warner, A. M. (2012) Impact Evaluation of Business License Simplification in Peru: An Independent; Assessment of an International Finance Corporation-Supported Project, IFC, October, Report No. 74469

Wennmann A., Ganson, B., \& Luiz, J. (2017) Operational Experience of Business Environment Reform Programming in Fragile and Conflict-Affected States Business Environment Reform Facility

White, S. and Fortune, P. (2015) Business Environment Reform and Poverty: Rapid Evidence Assessment, London: Coffey International Development

World Bank (2008) Doing Business: Women in Africa, Washington D.C.: World Bank

World Bank (2013) Understanding Regulations for Small and Medium-Size Enterprises, Washington, D.C.: World Bank

\section{Suggested citation}

Macdonald, K. (2021). The impact of business environment reforms on poverty, gender and inclusion. K4D Helpdesk Report No.898. Brighton, UK: Institute of Development Studies. DOI: 10.19088/K4D.2021.006

\section{About this report}

This report is based on twelve days of desk-based research. The K4D research helpdesk provides rapid syntheses of a selection of recent relevant literature and international expert thinking in response to specific questions relating to international development. For any enquiries, contact helpdesk@k4d.info.

K4D services are provided by a consortium of leading organisations working in international development, led by the Institute of Development Studies (IDS), with Education Development Trust, Itad, University of Leeds Nuffield Centre for International Health and Development, Liverpool School of Tropical Medicine (LSTM), University of Birmingham International Development Department (IDD) and the University of Manchester Humanitarian and Conflict Response Institute (HCRI).

This report was prepared for the UK Government's Foreign, Commonwealth and Development Office (FCDO) and its partners in support of pro-poor programmes. Except where otherwise stated, it is licensed for non-commercial purposes under the terms of the Open Government Licence v3.0. K4D cannot be held responsible for errors, omissions or any consequences arising from the use of information contained in this report. Any views and opinions expressed do not necessarily reflect those of FCDO, K4D or any other contributing organisation.

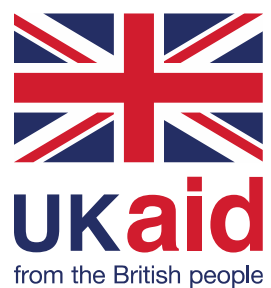

(c) Crown copyright 2021. 